DOI: $\underline{10.20472 / B M .2020 .8 .2 .001 ~}$

\title{
THE SURVEY OF CAUSAL RELATIONSHIPS BETWEEN CSR AWARENESS AND CORPORATE TRUSTWORTHINESS AS WELL AS THE OTHER DEPENDENT VARIABLES (ON THE EXAMPLE OF PETROLEUM COMPANIES OPERATING IN GEORGIA)
}

\section{ZOHREH ALIZADEHRAD, EKATERINE MAGLAKELIDZE}

\begin{abstract}
:
The objective of current research is to evaluate the impact of petroleum companies' CSR activities on corporate trustworthiness as one of the dimensions of corporate credibility, customer purchase intention, and customer's willingness to be involved in CSR initiatives in Tbilisi city of Georgia. In order to meet research objective and to test hypotheses generated at the outset of the research project causal research was applied; The experimental design that was used is before-after with control group. The population under study is customers of three petroleum companies out of six operating in the industry because these three companies have been showing commitment to CSR compared to their competitors. Three experiments were carried out using three experimental and three control groups. Each company's customers were randomly assigned to the experimental and the control groups. For the purpose of data analysis, a statistical package for social science (SPSS) was applied to assess group mean difference and to test research hypotheses at $p$-value 0.05 significance level. All three experiments revealed that CSR awareness significantly influences both corporate trustworthiness, which is one of the important dimensions of corporate credibility, and customer purchase intention, and ultimately results in more customer willingness to be involved in corporate CSR initiatives while the factor of corporate trustworthiness serves as a mediator between CSR awareness and Purchase Intention.
\end{abstract}

\section{Keywords:}

CSR, purchase intention, customer involvement in CSR activities, Georgian petroleum companies, experimental research, group mean comparison, ANOVA

JEL Classification: M14, M31, D21

\section{Authors:}

ZOHREH ALIZADEHRAD, University of Georgia, Georgia, Email: alizade.zohre@gmail.com EKATERINE MAGLAKELIDZE, University of Georgia, Georgia, Email: eka_maglakelidze@mail.ru

\section{Citation:}

ZOHREH ALIZADEHRAD, EKATERINE MAGLAKELIDZE (2020). The survey of causal relationships between CSR awareness and corporate trustworthiness as well as the other dependent variables (on the example of petroleum companies operating in Georgia). International Journal of Business and 
Management, Vol. VIII(2), pp. 1-24., 10.20472/BM.2020.8.2.001 


\section{Introduction}

Over the last few decades, corporate social responsibility (CSR) has spread extensively within the global community. Energy industry has faced a variety of concerns related to environmental and social issues for the last decades. The energy industry companies face environmental, health, safety and reputational risks that are critical to the corporations' long-term success and existence. Energy industry is expected to meet higher standards of environmental performance. Citizens, environmental and government organizations define energy company environmental and social responsibility as the duty. That means that for energy companies CSR is a requirement (Jelena Stjepcevic, Indre Siksnelyte, 2017). Although a lot of research has been done on the topic of Corporate Social Responsibility, Feldman and Vasquez-Parraga argued that specific on the topic of customer's response towards CSR activities were far from being settled and still debatable. There were several studies that found CSR activities had a strong and direct influence on customer responses (I. Butt,.2016, A. H. Khamah, B. K. Njehia, and L. W. Njanja, 2015, R. A. Rahim, F. W. Jalaludin, and K. Tajuddin, ,2011, S. W. Carvalho, S. Sen, M. de Oliveira Mota, and R. C. de Lima,2010, P. S. Ellen, 2006, 2006. V. Smith and P. Langford, 2009) However, other studies are also available that found such relationship as weak and even non-significant (I. Ali, K. U. Rehman, A. K. Yilmaz, S. Nazir, and J. F. Ali.,2010, M. Fatma, Z. Rahman, and I. Khan, ,2015, M. Fatma and Z. Rahman, 2016, C. Valor,2008). Furthermore, many studies were carried out in developed countries regarding the significance of corporate CSR activities to customers when making their purchase decisions. Compared to that, fewer studies have been conducted in developing countries in this field.

In Georgia, that is a developing country, CSR does not have a long history and this field is not studied well. In the face of growing attention to corporate social responsibility (CSR) activities in the marketplace, this paper seeks to demonstrate how corporate social responsibility (CSR) initiatives influence customer purchase intention in the context of Georgian petroleum market. Since the concept of corporate social responsibility in Georgia is relatively new in all sectors of economy, there is hardly any data available on the level of customer satisfaction and/or customer trust toward the companies who practice CSR. In fact, no previous research is available, at least in the public domain. To fill in this gap, the research was undertaken to measure the impact of corporate trustworthiness as a moderating variable between CSR awareness and purchase intention and customer willingness to be involved in corporate CSR initiatives.

According to the above arguments, three hypotheses were generated at the outset of the research project:

Hypothesis 1. Causal relationship exists between CSR awareness and corporate trustworthiness as one of the dimensions of Corporate Credibility; 
Hypothesis 2. Causal relationship exists between CSR awareness and customer willingness to be involved in corporate CSR activities;

Hypothesis 3. Causal relationship exists between CSR awareness and customer Purchase Intention.

For examining the hypotheses experimental research was conducted in Tbilisi city through which primary data have been collected. Secondary data are used only as a basis for theoretical analysis of the matter. This paper contributes to existing CSR literature by offering a deeper understanding into CSR dynamics and its effect on consumer purchase intention. Further, the study tests the level of consumer awareness of CSR activities in a real market situation (not artificial or simulated) which has not been done in previous studies in Georgia. The research instruments (questionnaires) were specially designed separately for the control and experimental groups. At total, three experimental and three control groups were created (one experimental and one control group per company). Considering three Petroleum companies namely Wissol, Socar, and Rompetrol, a total of 915 questionnaires were distributed among customers and at the end, only 615 of them were used for the analyzing the obtained data. Study participants of each company under study were divided into two groups and were randomly assigned to the control and experimental groups. Among others, the questionnaire for the control group contained demographic questions to measure demographic profile (age, gender, occupation, and education) of the respondents, also questions to measure their trust towards the petroleum companies, their purchase intentions and their willingness to be involved in corporate CSR activities. Exactly the same variables have been measured in the experimental group with only one distinction - the participants of the experimental group were informed about the companies' CSR activities to observe any possible differences in customers' behavior (namely, their trust toward the companies as a moderating variable and resulted purchase intention and willingness to be involved in corporate CSR activities) between the control and the experimental group. Thus, the control group was used only to isolate the effects of independent variable (customer awareness of companies' CSR activities) to the dependent variables (corporate trustworthiness, purchase intention, and willingness to be involved in corporate CSR activities) while also controlling the effects of any extraneous variables. CSR awareness checks were applied only in the experimental groups to see how it affects customer trustworthiness, their purchase intention and customer willingness to be involved in corporate CSR activities. For the purpose of the analysis, the statistical package for social sciences (SPSS) was applied. This study found that the statistically significant relationship exists between CSR awareness and corporate trustworthiness, CSR awareness and customer purchase intention, and ultimately between CSR awareness and customers' willingness to be involved in 
corporate CSR initiatives. The factor of corporate trustworthiness serves as a mediator between CSR awareness and Purchase Intention.

\section{Literature review:}

\section{Research Question/Theoretical contextualization}

The term CSR was introduced by Howard Bowen who believed that CSR was the obligatory decisions, policies, lines of actions for corporations that met the objectives and values of society in which they operate (Howard R. Bowen, 1953). Social responsiveness was the decade spanning 1960s to1970s, and 1980 to 1990 was the decade of CSR became business ethics. The modern era for CSR started in the 1990s and was called the decade of global citizenship (Andrew, 2008). In 1991, Carroll proposed a comprehensive definition for CSR comprising multi-dimension responsibility such as economic, legal, ethical and philanthropic factors. This is known as Carroll pyramid. Indeed, he delineated firms' responsibility into four categories. The first two layers emphasize the issue of profit maximization for the firms and the second two layers are the responsibilities for stakeholders' welfare (B.Carroll, Archie, 1991). The European Commission defines CSR as "A concept whereby companies integrate social and environmental concerns into their business operations and their interactions with stakeholders on a voluntary basis" (Communities, Commission of European, 2001). Corporations seek routes to sustainable development and retention of market share in tough competitive situations. In order to achieve these goals, investing in social projects that result in incremental gains to customer welfare, guarantees the existence of the corporation in the market with long-term financial flow, which is deemed obligatory for corporations. Corporate Social Responsibility (CSR) has emerged as a business approach for addressing the social and environmental impact of company activities. Companies from the oil and gas sector have been at the center of CSR development. With increasing expectations placed on business, one needs to ask if CSR is able to fulfill these larger expectations (Frynas, Jedrzej George, 2009). According to some research such as findings from research in Indian banking sector, corporate ability has a strong effect on customer purchase intention while CSR activities were found to exert influence on customer purchase intention in cases where the customer was aware of such activities being conducted (Mobin Fatma, Zillur Rahman 2016).

Further research founds that a company with good ethical reputation somehow perceived as a socially responsible company which lead to an increase in the number of customers (E. H. Creyer,1997). In addition, several researches had shown that corporate credibility somehow influence consumer buying behavior (L. Gatti, A. Caruana, and I. Snehota,2012, A. Caruana, C. Cohen, and K. A. Krentler,2006). Corporate credibility forms part of the overall reputation of a company. It describes how consumers evaluate the company's honesty and expertise. Company credibility was 
defined as representation from company actions in the past and its ability to create value for stakeholders (C. Fombrun and C. van RielJul. 199). Good reputation can produce trust and integrity [29] (H. Afzal, M. A. Khan, K. ur Rehman, I. Ali, and S. Wajahat, 2009) and when handle with care could also produce positive impact to the company in terms of cash and profitability by enhancing consumer perception on product quality (K. Weigelt and C. Camerer, 1988).

According to the above arguments, in order to achieve sustainable development of companies and societies, CSR is an issue that needs to be addressed more and its impact in different sectors should be examined. It is worth to note that based on the research which is done on investigated CSR research situation in the world, Georgia does not have any role in this ranking (Niccolò Pisani, Arno Kourula, Ans Kolk, Renske Meijer, 2017) and it shows a huge gap which should be filled in by studying and researching academically and tested in a real field of business.

The studies aimed at assessing the matter of corporate CSR from the customers' perspective, have not been yet conducted in Georgia. Hence, the current study investigates the customer's attitudes towards the three petroleum companies operating in the country. The main question of this research is to find out whether the awareness of CSR affects the corporate credibility. Theoretical framework and three hypotheses were developed based on the above arguments:

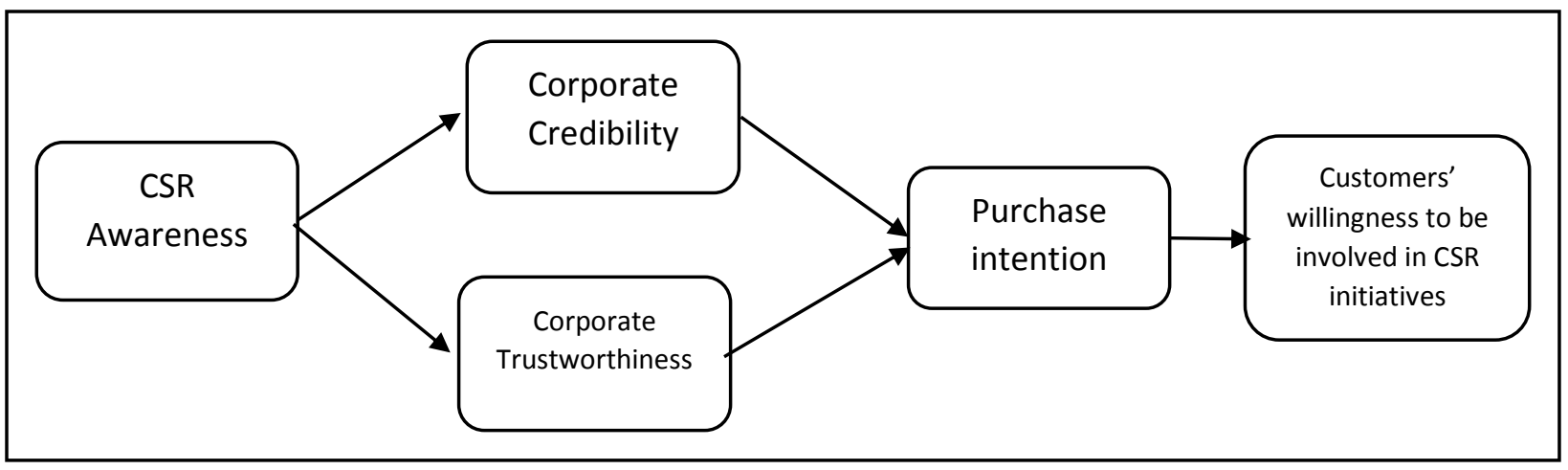

Figure 1: Theoretical Framework

H1. Causal relationship exists between CSR awareness and corporate trustworthiness as one of the dimensions of Corporate Credibility;

H2. Causal relationship exists between CSR awareness and customer willingness to be involved in corporate CSR activities;

H3. Causal relationship exists between CSR awareness and customer Purchase Intention. 


\section{Method and Data}

\section{a) Experimental Research Design Used}

In order to meet research objectives and to test the hypotheses generated at the outset of the research project, the true experimental design - Before-After with Control Group was applied. Three separate experiments were carried out simultaneously during the specific period of time (2 weeks) in each company, at total 9 experiments. Each selected experimental design considers two consecutive measurements of the dependent variable in the experimental group before and after changing the independent variable, and respectively, two consecutive measurements of the dependent variable in the control group without changing the independent variable. In all three experiments the independent (manipulated) variable is "customer awareness of the companies' CSR activities" and the dependent variables are: corporate trustworthiness, customer willingness to be involved in corporate CSR activities, and customer intention to buy. Under each experiment, customer awareness of the companies' CSR activities was manipulated in the experimental group to see how the changes in this variable affect the respective dependent variables while holding everything unchanged in the control group to eliminate the effects of extraneous variables on the dependent variables.

Below You can see the three Experimental Designs developed for the purpose to test the hypotheses generated at the outset of the study.

Experimental Designs for testing the first research hypothesis - "Causal relationship exists between CSR awareness and corporate trustworthiness as one of the dimensions of Corporate Credibility".

\section{Experimental group: $\mathrm{O}_{1} \times \mathrm{O}_{2}$}

Where,

$\mathrm{O}_{1}$ - the measurement of corporate trustworthiness before changing the independent variable (Pre - CSR awareness test);

$\mathrm{O}_{2}$ - the measurement of corporate trustworthiness after changing the independent variable (Post- CSR awareness test);

\section{Control group: $\quad \mathrm{O}_{3} \mathrm{O}_{4}$}

Where,

$\mathrm{O}_{3}$ - the measurement of corporate trustworthiness before the experiment without changing the independent variable; 
$\mathrm{O}_{4}$ - the measurement of corporate trustworthiness after the experiment without changing the independent variable.

Experimental Effect $\left(E_{H 1}\right)=\left(O_{2}-O_{1}\right)-\left(O_{4}-O_{3}\right)$

Experimental Designs for testing the second research hypothesis - "Causal relationship exists between CSR awareness and customer willingness to be involved in corporate CSR activities".

\section{Experimental group: $\mathrm{O}_{5} \times \mathrm{O}_{6}$}

Where,

$\mathrm{O}_{5}$ - the measurement of customer willingness to be involved in corporate CSR activities before changing the independent variable (Pre - CSR awareness test);

$\mathrm{O}_{6}$ - the measurement of customer willingness to be involved in corporate CSR activities after changing the independent variable (Post- CSR awareness test).

\section{Control group: $\quad \mathrm{O}_{7} \mathrm{O}_{8}$}

Where,

$\mathrm{O}_{7}$ - the measurement of customer willingness to be involved in corporate CSR activities before the experiment without changing the independent variable;

$\mathrm{O}_{8}$ - the measurement of customer willingness to be involved in corporate CSR activities after the experiment without changing the independent variable.

Experimental Effect $\left(E_{H 2}\right)=\left(O_{6}-O_{5}\right)-\left(O_{8}-O_{7}\right)$

Experimental Designs for testing the third research hypothesis - "Causal relationship exists between CSR awareness and customer Purchase Intention".

\section{Experimental group: $O_{9} X O_{10}$}

Where,

O9 - the measurement of customer purchase intention before changing the independent variable (Pre - CSR awareness test);

$\mathrm{O}_{10}$ - the measurement of customer purchase intention after changing the independent variable (Post- CSR awareness test).

\section{Control group: $\quad \mathrm{O}_{11} \mathrm{O}_{12}$}

Where,

$\mathrm{O}_{11}$ - the measurement of customer purchase intention before the experiment without changing the independent variable; 
$\mathrm{O}_{12}$ - is the measurement of customer purchase intention after the experiment without changing the independent variable.

Experimental Effect $\left(E H_{3}\right)=\left(O_{10}-O_{9}\right)-\left(O_{12}-O_{11}\right)$

\section{b) The Results of Descriptive Research Held Prior to the Experiment.}

The descriptive research has been conducted prior to the experiment to measure customer demographics, CSR awareness, correlations between customer awareness and corporate trustworthiness, customer awareness and customer willingness to be involved in CSR activities, and customer awareness and customer purchase intentions.

The relationships between variables under study have been measured by using multiple regressions technique.

Table 1.

The Results of Multiple Regression

\begin{tabular}{|l|l|l|l|l|l|}
\hline \multirow{2}{*}{ Model } & \multicolumn{2}{|l|}{$\begin{array}{l}\text { Unstandardized } \\
\text { Coefficients }\end{array}$} & $\begin{array}{l}\text { Standardized } \\
\text { Coefficients }\end{array}$ & t-value & Sig. \\
\cline { 2 - 5 } & $\mathrm{B}$ & Std. Error & Beta & & 0.000 \\
\hline (constant) & 0.69 & 0.116 & & 0.778 & 0.010 \\
\hline Trustworthiness & 0.135 & 0.052 & 0.138 & 3.514 & 0.000 \\
\hline $\begin{array}{l}\text { Customer willingness to be involved } \\
\text { in CSR activities }\end{array}$ & 0.335 & 0.052 & 0.37 & 1.86 & 0.000 \\
\hline Purchase intention & 0.173 & 0.049 & 0.215 & & \\
\hline
\end{tabular}

Based on figures in Table 1, the significant relationships are revealed between the variables of interest, respectively, customer CSR awareness and company trustworthiness (the significance is 0.01 ), CSR awareness and customers' willingness to be engaged in companies' CSR activities (significance is 0.000), and CSR awareness and customer's intention to buy the product (significance is 0.000 ). The number of study participants per company is shown in the Table 2.

Table 2.

Number of Study Participants per Company

\begin{tabular}{|c|l|c|c|c|c|c|c|}
\hline \multirow{2}{*}{$\begin{array}{c}\text { Total } \\
\text { Participants }\end{array}$} & $\begin{array}{c}\text { Selected } \\
\begin{array}{c}\text { Petroleum } \\
\text { Company }\end{array}\end{array}$ & \multicolumn{2}{|c|}{ Participants } & \multicolumn{2}{c|}{ Control Group } & \multicolumn{2}{c|}{ Experimental Group } \\
\cline { 3 - 8 } & Percent & $\mathrm{N}$ & Percent & $\mathrm{N}$ & Percent & $\mathrm{N}$ \\
\hline \multirow{3}{*}{615} & Wisol & $36 \%$ & 221 & $50 \%$ & 111 & $50 \%$ & 111 \\
\cline { 2 - 7 } & Socar & $33 \%$ & 203 & $50 \%$ & 101 & $50 \%$ & 101 \\
\cline { 2 - 7 } & Rompetrol & $31 \%$ & 191 & $50 \%$ & 95 & $50 \%$ & 95 \\
\hline & Total & $100 \%$ & 615 & & 307 & & 307 \\
\hline
\end{tabular}




\section{The Description of the Experiments held in Three petroleum Companies (Wissol Petroleum, Socar Petroleum and Rompetrol)}

The experiments were held in three petroleum companies: Wissol Petroleum, Socar Petroleum and Rompetrol to test the hypotheses generated at the outset of research project.

Initially the corporate trustworthiness as a first dependent variable was measured in the experimental group and the mean was calculated (Pre-CSR awareness test $\left(\mathrm{O}_{1}\right)$ ); then the pamphlets developed in collaboration with each of the three of the companies under studies were sent to the participants of the experimental group to raise their awareness about company CSR activities and after 2 weeks the corporate trustworthiness was measured again in the experimental group using the questionnaire specially developed for Post-CSR testing and the mean was calculated for each company participants (PostCSR awareness test $\left.\left(\mathrm{O}_{2}\right)\right)$. Two consecutive measurements of the corporate trustworthiness were also made in the Control Group ( $\mathrm{O}_{3}$ and $\mathrm{O}_{4}$, respectively) to gauge mean differences between experimental and control groups. In this way the experimental effect was calculated for testing the 1st hypothesis (Experimental Effect $\left.\left(\mathrm{EH}_{1}\right)=\left(\mathrm{O}_{2}-\mathrm{O}_{1}\right)-\left(\mathrm{O}_{4}-\mathrm{O}_{3}\right)\right)$.

The same procedures were applied to measure the effects of independent variable (CSR Awareness) on two other dependent variables - customer willingness to be involved in CSR activities and customer purchase intention. See the description of the experiments in the table below.

Table 3.

The Description of the Experiments held in Three Petroleum Companies

\begin{tabular}{|c|c|c|c|c|c|c|}
\hline \multirow[t]{4}{*}{ No. } & \multirow{4}{*}{$\begin{array}{l}\text { Dependent } \\
\text { Variables }\end{array}$} & \multicolumn{4}{|c|}{ Test } & \multirow{4}{*}{$\begin{array}{c}\text { Experimental Effect (EH) } \\
\text { Control Group vs. Experimental } \\
\text { Group }\end{array}$} \\
\hline & & \multicolumn{2}{|c|}{ Experimental Group } & \multicolumn{2}{|c|}{ Control Group } & \\
\hline & & $\begin{array}{l}\text { Before CSR } \\
\text { Awareness }\end{array}$ & $\begin{array}{l}\text { After CSR } \\
\text { Awareness }\end{array}$ & (Pre-CSR) & (Post-CSR) & \\
\hline & & (Pre-CSR) & (Post-CSR) & & & \\
\hline \multirow[t]{4}{*}{$\mathrm{H} 1$} & \multicolumn{6}{|c|}{ Corporate Trustworthiness } \\
\hline & Wisol & OW1 & OW2 & OW3 & OW4 & $E H W 1=(O W 2-O W 1)-(O W 4-O W 3)$ \\
\hline & Socar & OS1 & Os2 & OS3 & OS4 & $\mathrm{EHS} 1=(\mathrm{OS} 2-\mathrm{OS} 1)-(\mathrm{OS} 4-\mathrm{OS} 3)$ \\
\hline & Rompetrol & OR1 & OR2 & OR3 & OR4 & $E H R 1=(O R 2-O R 1)-(O R 4-O R 3)$ \\
\hline \multirow[t]{4}{*}{$\mathrm{H} 2$} & \multicolumn{6}{|c|}{ Customer willingness to be involved in CSR activates } \\
\hline & Wisol & OW5 & OW6 & OW7 & OW8 & $\mathrm{EHW} 2=(\mathrm{OW6} 6 \mathrm{OW} 5)-(\mathrm{OW} 8-\mathrm{OW} 7)$ \\
\hline & Socar & OS5 & Os6 & OS7 & OS8 & $\mathrm{EHS} 2=(\mathrm{OS} 6-\mathrm{OS} 5)-(\mathrm{OS} 8-\mathrm{OS} 7)$ \\
\hline & Rompetrol & OR5 & OR6 & OR7 & OR8 & $\mathrm{EHR} 2=(\mathrm{OR} 6-\mathrm{OR} 5)-(\mathrm{OR} 8-\mathrm{OR} 7)$ \\
\hline \multirow[t]{2}{*}{ H3 } & \multicolumn{6}{|c|}{ Purchase intention } \\
\hline & Wisol & Ow9 & OW10 & OW11 & OW12 & $E H W 3=(O W 10-O W 9)-(O W 12-O W 11)$ \\
\hline
\end{tabular}




\begin{tabular}{|l|l|l|l|l|l|l|}
\hline & Socar & OS9 & OS10 & OS11 & OS12 & EHS3= (OS10-OS9) - (OS12-OS11) \\
\cline { 2 - 6 } & Rompetrol & OR9 & OR10 & OR11 & OR12 & EHR3= (OR10-OR9) - (OR12-OR11) \\
\hline
\end{tabular}

\section{Research Outcomes}

As it is clear from the table 3, experimental effects were calculated tested by comparing the differences between the means obtained in the experimental groups with the differences obtained between the means of the control groups ${ }^{1}$ in the frame of three separate experiments held in three petroleum companies.

In order to identify whether the statistically significant differences exist between the PreCSR and Post CSR group averages in the experimental group and to test the hypotheses generated at the outset of the research project, t-test was applied for each cases using $95 \%$ confidence interval. ${ }^{2}$

The experimental effects are shown in the table 4 followed by the comparative analyses.

Table 4.

\section{Comparisons of Effects of CSR Awareness in the Control and Experimental Groups}

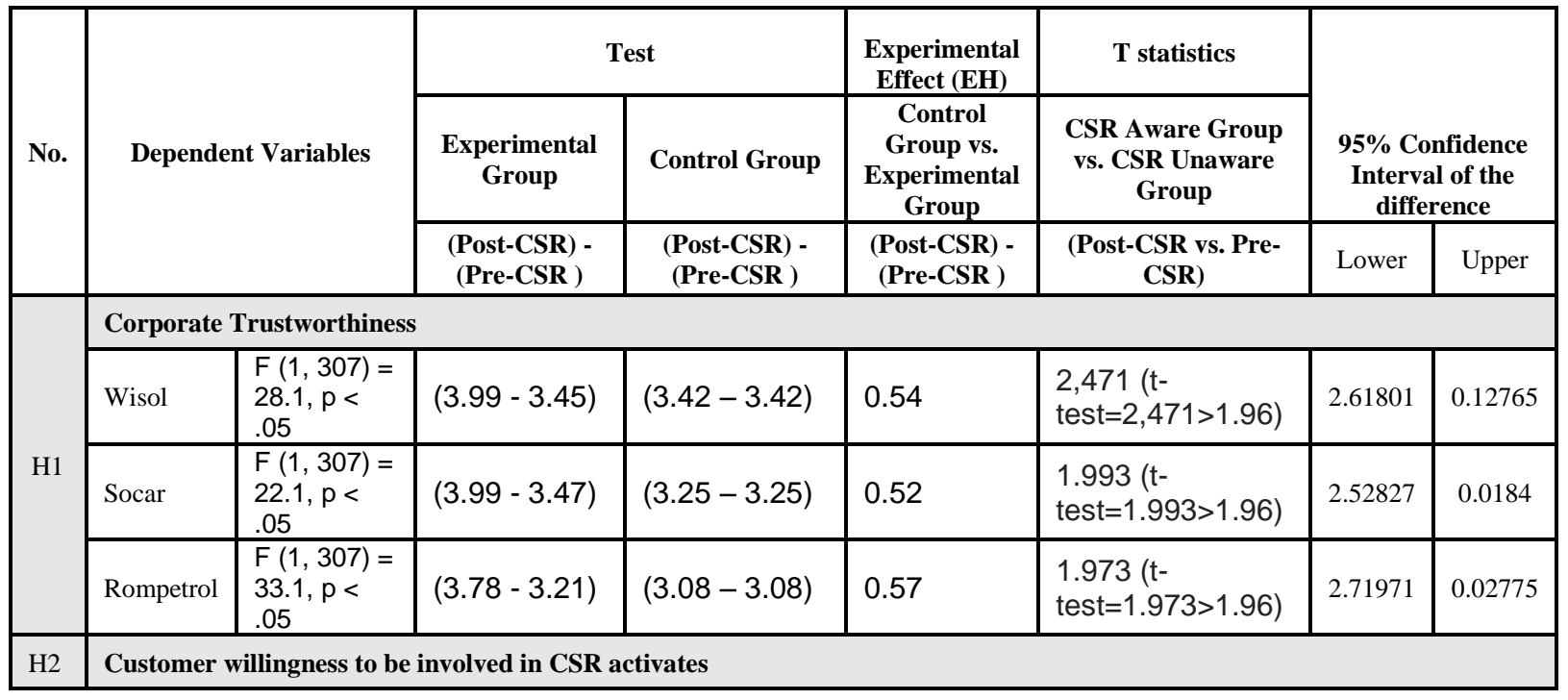

\footnotetext{
1 See the Annex 2 that contains the means for each of the groups

2 Since the null differences were obtained between two averages in the control group, t-test was applied only to the Experimental Group
} 


\begin{tabular}{|c|c|c|c|c|c|c|c|c|}
\hline & Wisol & $\begin{array}{l}F(1,307)= \\
12.9, p< \\
.05\end{array}$ & $(3.98-3.24)$ & $(3.25-3.25)$ & 0.74 & $\begin{array}{l}2,576 \text { (t-test }= \\
2.576>1.96)\end{array}$ & 2.91901 & 0.13874 \\
\hline & Socar & $\begin{array}{l}F(1,307)= \\
10.9, p< \\
.05\end{array}$ & $(3.99-3.31)$ & $(3.29-3.29)$ & 0.68 & $\begin{array}{l}2.839 \text { (t-test }= \\
2.839>1.96)\end{array}$ & 2.82421 & 0.12935 \\
\hline & Rompetrol & $\begin{array}{l}F(1,307)= \\
12.7, p< \\
.05\end{array}$ & $(3.92-3.22)$ & $(3.10-3.10)$ & 0.7 & $\begin{array}{l}2,597 \text { (t-test }= \\
2.597>1.96)\end{array}$ & $\begin{array}{l}2.83 \\
222\end{array}$ & 0.14563 \\
\hline \multirow{4}{*}{ H3 } & \multicolumn{8}{|c|}{ Purchase intention } \\
\hline & Wisol & $\begin{array}{l}F(1,307)= \\
32.0, p< \\
.05\end{array}$ & $(3.91-3.38)$ & (3.37-3.37) & 0.53 & $\begin{array}{l}1,990 \text { (t-test } \\
=1.990>1.96)\end{array}$ & 2.11876 & 0.02798 \\
\hline & Socar & $\begin{array}{l}F(1,307)= \\
32.0, p< \\
.05\end{array}$ & $(3.98-3.43)$ & $(3.41-3.41)$ & 0.55 & $\begin{array}{l}1,973 \text { (t-test } \\
=1.973>1.96)\end{array}$ & 2.31504 & 0.12565 \\
\hline & Rompetrol & $\begin{array}{l}F(1,307)= \\
32.2, p< \\
.05\end{array}$ & $(3.86-3.29)$ & $(3.27-3.27)$ & 0.57 & $\begin{array}{l}1,997 \text { (t-test } \\
=1.997>1.96)\end{array}$ & 2.41918 & 0.1254 \\
\hline
\end{tabular}

** Significant difference between post-CSR experimental group and pre-CSR experimental group at * $\mathrm{p}<0.05$

As it was assumed, post-CSR experimental group had stronger corporate trustworthiness than the pre-CSR experimental group in all three petroleum companies, $F(1,307)=\ldots . p<.05$. The difference occurred only in the experimental group [(PostCSR - Pre-CSR)] while the difference in the control group [(Post-CSR - Pre-CSR)] was null.

For the hypothesis ( $\mathrm{H} 1)$, this study expected that corporate's trustworthiness to be greater in the aware experimental group (Post-CSR group) than that of unaware experimental group (Pre-CSR group). Therefore, this hypothesis was tested using a ttest to compare mean scores for corporate trustworthiness between two groups. ${ }^{3}$ Computed t value (t-test $>1.96$ ). It means that there is statistically significant difference between Post-CSR and Pre-CSR experimental groups in regard of corporate trustworthiness in all three companies. Thus, the experiment carried out in petroleum companies revealed the statistically significant and positive relationship between customers' CSR awareness and company trustworthiness that gives us enough evidence to say that the first hypothesis $(\mathrm{H} 1)$ asserting that "Causal relationship exists between CSR awareness and corporate trustworthiness as one of the dimensions of Corporate Credibility", is supported. This result is linked with prior studies on CSR that tested the effect of CSR on corporate credibility (Brammer \&Millington, 2005; Lichtenstein, Drumwright, \& Braig, 2004, Dutta and Singh (2013).

As it was assumed, post-CSR experimental group is more likely to be involved in corporate CSR activities than pre-CSR experimental group in all three petroleum companies, $F(1,307)=\ldots ., p<.05$. The difference occurred only in the experimental

3 A paired-samples t-test was appropriate for comparing the scores of two means related to the same respondents (Zikmund \& Babin 2010). 
group [(Post-CSR - Pre-CSR)] while the difference in the control group [(Post-CSR Pre-CSR)] was null.

For hypothesis $(\mathrm{H} 2)$ as well, this study expected that CSR aware experimental group would have shown more willingness to be involved in Petroleum companies' CSR activities than that of unaware experimental group. An independent-sample t-test was conducted to compare differences of the impact of CSR awareness on customer's willingness to be involved in CSR activities. Computed t value (t-test $>1.96$ ); It means that there is statistically significant difference between Post-CSR and Pre-CSR experimental groups in regard of their willingness to be involved in Petroleum companies' CSR activities. Thus this experiment also revealed the statistically significant and positive relationship between CSR awareness and customers' willingness to be involved in corporate CSR activities that gives us enough evidence to say that the 2nd hypothesis $(\mathrm{H} 2)$ asserting that the "Causal relationship exists between CSR awareness and customer willingness to be involved in corporate CSR activities", is also supported. The result of this study is consistent with the studies of Orlitzky, Siegel, \& Waldman, 2011.

As it was assumed, post-CSR experimental group displayed stronger purchase intention than the pre-CSR experimental group in all three petroleum companies, $F(1,307)=\ldots$, $p<.05$. The difference occurred only in the experimental group [(Post-CSR - Pre-CSR)] while the difference in the control group [(Post-CSR - Pre-CSR)] was null.

For Hypothesis $(\mathrm{H} 3)$, as well, this study expected that purchase intention of aware experimental group would have shown more than purchase intention of that of unaware experimental group. An independent-sample t-test was conducted to compare differences of the impact of CSR awareness on customer's willingness to be involved in Petroleum companies' CSR activities. Computed t value (t-test $>1.96$ ). It means that there is statistically significant difference between Post-CSR and Pre-CSR experimental groups in regard of customer's purchase intention. Thus, the experiment conducted in petroleum companies also revealed the statistically significant and positive relationship between CSR awareness and customers' purchase intention that gives us enough evidence to say that the 3rd hypothesis $(\mathrm{H} 3)$ asserting that the "Causal relationship exists between CSR awareness and customer purchase intention", is also supported even though computed $t$ value barely exceeds the critical $Z$ value $(1,96)$ associated with the chosen level of confidence ( $95 \%$ confidence level). The result of this study is consistent with the results of previous studies which have investigated the impact of CSR awareness on customers' purchase intention (Ki-Hoon lee \& Dongyoung, 2010; Yu-Shan, C, \& Chang, C. 2010; Mohr and Webb, 2005' Becker-Olsen et al., 2006).

Thus, based on the results obtained through the experiments held in three petroleum companies, all research hypotheses are supported. See the table 5. 
Table 5.

\section{Summary of Hypothesis Testing}

\begin{tabular}{|c|c|c|c|}
\hline COMAPNY & & Hypothesis & Results \\
\hline Wisol & \multirow{3}{*}{$\mathrm{H} 1$} & \multirow{3}{*}{$\begin{array}{l}\text { Causal relationship exists between CSR } \\
\text { awareness and corporate trustworthiness as } \\
\text { one of the dimensions of Corporate } \\
\text { Credibility }\end{array}$} & \multirow{3}{*}{ Supported } \\
\hline Socar & & & \\
\hline Rompetrol & & & \\
\hline Wisol & \multirow{3}{*}{$\mathrm{H} 2$} & \multirow{3}{*}{$\begin{array}{l}\text { Causal relationship exists between CSR } \\
\text { awareness and customer willingness to be } \\
\text { involved in corporate CSR activities }\end{array}$} & \multirow{3}{*}{ Supported } \\
\hline Socar & & & \\
\hline Rompetrol & & & \\
\hline Wisol & \multirow{3}{*}{$\mathrm{H} 3$} & \multirow{3}{*}{$\begin{array}{l}\text { Causal relationship exists between CSR } \\
\text { awareness and customer Purchase } \\
\text { Intention }\end{array}$} & \multirow{3}{*}{ Supported } \\
\hline Socar & & & \\
\hline Rompetrol & & & \\
\hline
\end{tabular}

It is also worthy to note that effects of CSR awareness on dependent variables (corporate trustworthiness, customers' willingness to be involved in corporate CSR activities, and customer purchase intention) do not vary much between the companies. Although the statistically significant relationships are revealed between the variables of interest regarding each petroleum companies, the differences in the statistical results of the experiment for individual companies are small.

\section{Conclusions}

Today's concern of companies in a competitive market is to increase sales. On the other hand, sustainable competitive advantage has long been a major issue for corporate executives. To achieve this sustainable competitive advantage, it is necessary to address the issue of corporate social responsibility, which in the current context should be an integral part of corporate marketing strategy. Our study responds to the already established megatrend in the marketplace that the investments in corporate CSR are exclusively made for the purpose to meet the industry standard and to create the necessary points-of-parities (POPs) just to match with competition through establishing the strong and favorable image of corporation in the society. But our study is also the additional prove to the fact that in order to be successful in this direction, corporations must raise the awareness of their CSR activities among key stakeholder groups because corporate CSR awareness has the positive impact on corporate trustworthiness. Gaining more competitive advantage by impacting customer trust and building corporate credibility through CSR will lead to more organization sustainability and will create better society. 
To our knowledge, this is the first experimental study held in Georgia to investigate whether awareness of corporate social responsibility initiatives affects companies' credibility (from customers' perspective). Individuals who were aware of the corporate CSR initiatives, had displayed greater organizational trust to the companies being involved in the study, more willingness to be involved in corporate CSR activities as well as more intention to purchase companies' products than respondents who were unaware of the companies' CSR initiatives. Therefore, it can be argued that the CSR awareness has a positive effect on the companies' credibility and, ultimately, the customers' purchase intentions.

Answers received from the experiments conducted for the purpose to reveal whether the causal relationships exist between CSR awareness and corporate trustworthiness, customers' willingness to be involved in corporate CSR activities, and their intention to buy, gave us enough evidence to support all three hypotheses generated at the outset of the research project at $95 \%$ level of confidence.

Since the computed t-values in all nine cases are more than 1,96, that gives us enough evidence to say that the Pre-CSR (CSR non-aware group) and Post-CSR (CSR aware group) experimental groups differ significantly in regard with their corporate trustworthiness, customers' willingness to be involved in corporate CSR activities, and their intention to buy even though Post-CSR (aware) customers showed more trust toward companies under study, more willingness to be involved in their social responsibility activities than just to buy their products.

Thus, although statistically significant and positive relationships are reveled in all nine cases between the corporate CSR awareness and its resulting corporate trustworthiness, customers' willingness to be involved in corporate CSR activities, and their intention to buy, it is preferable that computed $t$ values were even higher than they are now. But it doesn't mean that petroleum companies must turn away from the already established megatrend in the marketplace and cease financing programs that have positive social consequences. Inversely, they should strengthen their care on society but find more appropriate ways to communicate their CSR activities to society.

Overall, this research demonstrates that given sufficient awareness, even a single realworld CSR initiative is capable of affecting behavioral intentions of customers as a main company's stakeholders. In other words, the study revealed that CSR awareness can be a key factor in raising company trustworthiness, customers' willingness to be involved in corporate CSR activates, and customers' purchase intentions through increasing corporate credibility.

We hope that our research will spur future investigations of stakeholder reactions to CSR announcements in real-world contexts. 


\section{Problem Solution}

A key problem that plagues many CSR studies is that awareness is either assumed or artificially induced. In reality, however, awareness of CSR initiatives is fairly low (Bhattacharya and Sen 2004). Based on our study results conducted in the country like Georgia, where study participants are aware of the corporate CSR initiatives only through standard outlets such as social media, newspaper reports and word of mouth, the concept of corporate social responsibility doesn't generate enough trust and loyalty towards corporations than in the society where people are involved in planning corporate CSR activities through the research. A key implication, therefore, is that to reap the positive benefits of CSR, companies need to work harder at raising awareness of their CSR activities. Of course, companies need to devise strategies for the optimal communication of their CSR actions to society.

\section{References}

Aqueveque, C. (2005). Marketing and Market Development Signaling Corporate Values: Consumers' Suspicious Minds. Corporate Governance 5(3), 70-81. https://doi.org/10.1108/14720700510604715

Auger, P., Devinney, T.M., Louviere, J.J., and Burke, P.F., (2010). Do social product features have value to consumers? International Journal of Research in Marketing,33 (1), pp.122136.

Bala, R. and M. Yeung. (2009). Chinese Consumers: Perception of Corporate Social Responsibility (CSR). Journal of Business Ethics Supplement 1(88), pp.119-132. https://doi.org/10.1007/s10551-008-9825-x

Barnham, C. (2015). Quantitative and qualitative research: perceptual foundations. International Journal of Market Research, 57(6), p.837. https://doi.org/10.2501/IJMR2015-070

Baron, D. P. (2001). Private politics, corporate social responsibility, and integrated strategy. Journal of Economics \& Management Strategy, 10(1), pp. 7-45. https://doi.org/10.1162/105864001300122548 
Becker-Olsen, K. L., B. A. Cudmore and R. P. Hill. (2006). The Impact of Perceived Corporate Social Responsibility on Consumer Behavior. Journal of Business Research 59(1), pp.46-53. https://doi.org/10.1016/j.jbusres.2005.01.001

Benoit, V., (2013). Corporate social responsibility in China. 2ed. Singapore: World Scientific Printers.

Bhattacharya, C. B. and S. Sen. (2004). Doing Better at Doing Good: When, Why, and How Consumers Respond to Corporate Social Initiatives. California Management Review .47(1), pp.9-24. https://doi.org/10.2307/41166284

Blomqvist, K. (1997). The Many Faces of Trust. Scan Dinavian Journal of Management. 13(3), pp.271-286. https://doi.org/10.1016/S0956-5221(97)84644-1

Bowen, H. (1953). Social Responsibility of the Businessman. New York: Harper.

Brown, T. J. and P. A. Dacin. (1997). The Company and the Product: Corporate Associations and Consumer Product Responses. Journal of Marketing, 61(1), pp.68- 84. https://doi.org/10.1177/002224299706100106

Brown, J. and Fraser, M. (2006). Approaches and Perspectives in Social and Environmental Accounting: An Overview of the Conceptual Landscape. Business Strategy and the Environment.15(1). pp.103-117. https://doi.org/10.1002/bse.452

Bryman, A. and Bell, E., (2007). Business Research Methods. 2ed., Great Clarendon: Oxford University Press.

Carrigan, M., I. Szmigin and J. Wright. (2004). Shopping for a Better World? An Interpretive Study of the Potential for Ethical Consumption Within the Older Market, The Journal of Consumer Marketing 21(6), pp.401-417. https://doi.org/10.1108/07363760410558672

Carroll, A. B. (1979). A Three-Dimensional Conceptual Model of Corporate Performance. Academy of Man- agreement Review.4(4), pp.497-505. https://doi.org/10.5465/amr.1979.4498296 
Carroll, A. B. (1991). The Pyramid of Corporate Social Responsibility: Toward the Moral Management of Organizational Stakeholders. Business Horizons ,34(4), pp.39- 48. https://doi.org/10.1016/0007-6813(91)90005-G

Clarkson, M. (1995). A Stakeholder Framework for Analyzing and Evaluating Corporate Social Performance. The Academy of Management Review, 20(1), pp.92-93. https://doi.org/10.5465/amr.1995.9503271994

Coulter, KS. and Coulter, RA. (2002). Determinants of trust in a service provider: the moderating role of length of relationship. Journal of Services Marketing,16(1), pp.3536. https://doi.org/10.1108/08876040210419406

Daub, C. and Ergenzinger, R. (2005). Enabling sustainable management through a new multi-disciplinary concept of consumer satisfaction. European Journal of Marketing, 39(9/10), pp.998-1012. https://doi.org/10.1108/03090560510610680

Denscombe, M. (2007). The Good Research Guide for small-scale social research projects. 3ed., Maidenhead: Open University Press.

Donaldson, T. and Preston, L. (1995). The stakeholder theory of the modern corporation: Concepts, evidence and implications, Academy of Management Review ,20, pp.65-91. https://doi.org/10.5465/amr.1995.9503271992

Dutta, K. and Singh, S. (2013). Consumer perception of CSR and its impact on retailer evaluation and purchase intention in India. Journal of Services Research,13(1), pp.111134.

Ellen, P.S., D.J. Webb and L.A. Mohr. (2006). Building Corporate Associations: Consumer Attributions for Corporate Socially Responsible Programs. Journal of the Academy of Marketing Science, 34(2), pp.147-157. https://doi.org/10.1177/0092070305284976

Erdem, T. and Swait, J. (2004). Brand Credibility, Brand Consideration, and Choice. Journal of Consumer Research, 31(1), pp.191-198. https://doi.org/10.1086/383434 
Esch, F., Langner, T., Schmitt, B. and Geus, P. (2006). Are brands forever? How brand knowledge and relationships affect current and future purchases. Journal of Product \& Brand Management, 15(2), pp.98-105. https://doi.org/10.1108/10610420610658938

Espejel, J., Fandos, C. and Flavián, C. (2008). Consumer satisfaction. British Food Journal, 110(9), pp.865-881. https://doi.org/10.1108/00070700810900585

Falck, O. and Heblich, S. (2007). Corporate social responsibility: Doing well by doing good. Business Horizons, 50(3), pp.247-254. https://doi.org/10.1016/j.bushor.2006.12.002

Freeman, R. (1999). Response: Divergent Stakeholder Theory. The Academy of Management Review, 24(2), p.233. https://doi.org/10.2307/259078

Freeman. (1984). Strategic Management: A Stakeholder Approach. Boston: Pitman Press.

Martínez, P., Perez, A., \& del Bosque, I. R. (2014). CSR influence on hotel brand image and loyalty. Academia Revista Latinoamericana de Administracion, 27(2), 267e283. https://doi.org/10.1108/ARLA-12-2013-0190

Mullerat, R., \& Brennan, D. (2005). Corporate social responsibility: The corporate governance of the 21st century. The Hague, The Netherlands: Kluwer Law International.

Norseman, A., \& Hassan, Z. (2013). Customer perceived practice of CSR on improving customer satisfaction and loyalty. International Journal of Accounting and Business Management, 1(1), 30e49.

Nasir, N. E. M., Halim, N. A. A., Sallem, N. R. M., Jasni, N. S., \& Aziz, N. F. (2015). Corporate social responsibility: An overview from Malaysia. Journal of Applied Environmental and Biological Sciences, 4(10S), 82e87.

Nemec, R. (2010). Integration of corporate social responsibility into loy-alty programs in the tourism industry. Tourism and Hospitality Man-agement, 16(1), 101e108.

Nyahunzvi, K. D. (2013). CSR reporting among Zimbabwe's hotel groups: A content analysis. International Journal of Contemporary Hospitality Management, 25(4), 595e613. https://doi.org/10.1108/09596111311322943 
Oliver, R. L. (2014). Satisfaction: A behavioral perspective on the consumer.New York, NY: Routledge. https://doi.org/10.4324/9781315700892

Othman, N. Z., \& Hemdi, M. A. (2013). Corporate social responsibility (CSR) activities, brand image, and hotel guest retention. Hospitality and Tourism: Synergizing Creativity and Innovation in Research, 17, 153e160. https://doi.org/10.1201/b16064-6

Poon, W., \& Low, K. L. (2005). Are travelers satisfied with Malaysian ho-tels? International Journal of Contemporary Hospitality Management, 17(3), $217 \mathrm{e} 227$. https://doi.org/10.1108/09596110510591909

Porter, M. E., \& Kramer, M. R. (2006). Strategy \& society: The link between competitive advantage and corporate social responsibility. Harvard Business Review, 84(12), 78e92.

Rashid, N. R. N. A., Rahman, N. I. A., \& Khalid, S. A. (2014). Environmental corporate social responsibility (ECSR) as a strategic marketing initiative. Procedia-Social and Behavioral Sciences, 130, 499e508. https://doi.org/10.1016/j.sbspro.2014.04.058

Reisinger, Y. (2009). International tourism: Cultures and behaviour. Oxford,UK: ButterworthHeinemann.

Ricks, J. M. (2005). An assessment of strategic corporate philanthropy on perceptions of brand equity variables. Journal of Consumer Marketing, 22(3), $121 \mathrm{e} 134$. https://doi.org/10.1108/07363760510595940

Romani, S., Grappi, S., \& Bagozzi, R. P. (2013). Explaining consumer re-actions to corporate social responsibility: The role of gratitude and altruistic values. Journal of Business Ethics, 114(2), 193e206. https://doi.org/10.1007/s10551-012-1337-z

Rowley, T., \& Berman, S. (2000). A brand new brand of corporate social performance. Business \& Society, 39(4), 397e418. https://doi.org/10.1177/000765030003900404 


\section{Annex 1. Content of Pamphlets}

Wissol's contemporary activities are mostly concentrated on multi-profile, long-term projects. It has been engaged in implementing several educational programs in the regions of Georgia with the title "Book for All the Villages", with over 150 regional libraries supplied with books. (source: annual report http://www.wissol.ge/\#page/csr).

Rompetrol has targeted its CSR groups based on establishing, implementing and maintaining a comprehensive QHSE Management system, it participates in blood donation Programs and promotes healthy life-style as a general sponsor and active supporter of the Georgian Weightlifting Federation for 4 years on local and international level which is the best world weightlifter of 2017 nominated by the International Weightlifting Federation (IWF). Its aim is to inspire young generation and promote healthy life-style for better and healthier future. (source: https://www.rompetrol.ge/en/company/csr)

Socar has based its CSR practices on the field of Environment protection. 4,700 trees were planted on 2 hectares of land damaged by the wildfire in Borjomi-Kharagauli National Park of Tbilisi, contributes to youth sports development in Georgia, mostly soccer and rugby. Over past years SOCAR initiated several women empowerment information campaigns. Raising awareness by means of vehicle sticker \# I know woman at steering wheel /With a woman\# for fighting the stereotypes. The company launched a campaign "Active lifestyle" that implies several sports events and extreme camps equipped with lifts, wheelchair ramps and special sports equipment for Enforcement of rights people with disabilities (PWD) and older people (source : http://www.sgp.ge/en/csr/) . 
Annex2.

\section{Demographic Description}

\begin{tabular}{|c|c|c|c|c|}
\hline \multirow[b]{2}{*}{ Variable } & \multicolumn{2}{|c|}{ Control Group } & \multicolumn{2}{|c|}{ Experimental Group } \\
\hline & Controll $(n=615)$ & Control2 $(\mathrm{n}=307)$ & $\operatorname{Pre}-\operatorname{CSR}(\mathrm{n}=307)$ & Post-CSR $(\mathrm{n}=307)$ \\
\hline \multicolumn{5}{|l|}{ Demographics } \\
\hline \multicolumn{5}{|l|}{ Gender } \\
\hline Male & $57.8 \%$ & $62.7 \%$ & $63.6 \%$ & $63.6 \%$ \\
\hline Female & $42.2 \%$ & $37.2 \%$ & $36.2 \%$ & $36.2 \%$ \\
\hline \multicolumn{5}{|l|}{ Age } \\
\hline 20-30 years & $7.2 \%$ & $6.9 \%$ & $6.5 \%$ & $6.5 \%$ \\
\hline $30-40$ years & $82.6 \%$ & $79.6 \%$ & $78.1 \%$ & $78.1 \%$ \\
\hline $40-50$ years & $10.2 \%$ & $12.8 \%$ & $15.4 \%$ & $15.4 \%$ \\
\hline \multicolumn{5}{|l|}{ Education } \\
\hline High school & $3.5 \%$ & $1.1 \%$ & $1.4 \%$ & $1.4 \%$ \\
\hline Diploma equivalent & $10.5 \%$ & $8.5 \%$ & $5.6 \%$ & $5.6 \%$ \\
\hline Bachelor degree & $50.0 \%$ & $56.8 \%$ & $49.8 \%$ & $49.8 \%$ \\
\hline Master degree / higher & $36 \%$ & $33.6 \%$ & $43.20 \%$ & $43.20 \%$ \\
\hline \multicolumn{5}{|l|}{ Occupation } \\
\hline Student & $34.9 \%$ & $35.40 \%$ & $34.87 \%$ & $34.87 \%$ \\
\hline Government officer & $5.9 \%$ & $5.95 \%$ & $5.89 \%$ & $5.89 \%$ \\
\hline Private employee & $43.5 \%$ & $42.99 \%$ & $43.47 \%$ & $43.47 \%$ \\
\hline Business/ Trade & $10.5 \%$ & $10.49 \%$ & $10.49 \%$ & $10.49 \%$ \\
\hline General & $5.2 \%$ & $5.17 \%$ & $5.15 \%$ & $5.15 \%$ \\
\hline
\end{tabular}

NOTE: CSR = corporate social responsibility. 


\section{Annex3.}

\section{Comparisons of Effects of CSR Awareness in the Control and Experimental Groups}

\begin{tabular}{|c|c|c|c|c|c|c|c|c|c|c|c|}
\hline \multirow{5}{*}{ No. } & \multirow{5}{*}{$\begin{array}{l}\text { Dependent } \\
\text { Variables }\end{array}$} & \multicolumn{8}{|c|}{ Mean (SD.) } & \multirow{2}{*}{\multicolumn{2}{|c|}{ Experimental Effect (EH) }} \\
\hline & & \multicolumn{4}{|c|}{ Experimental Group } & \multicolumn{4}{|c|}{ Control Group } & & \\
\hline & & \multicolumn{2}{|c|}{$\begin{array}{c}\text { Before CSR } \\
\text { Awareness } \\
\text { (Pre-CSR ) }\end{array}$} & \multicolumn{2}{|c|}{$\begin{array}{l}\text { After CSR } \\
\text { Awareness } \\
\text { (Post-CSR) }\end{array}$} & \multicolumn{2}{|c|}{ (Pre-CSR) } & \multicolumn{2}{|c|}{ (Post-CSR) } & \multirow{3}{*}{\multicolumn{2}{|c|}{$\begin{array}{l}\text { Control Group vs. Experimental } \\
\text { Group }\end{array}$}} \\
\hline & & \multicolumn{4}{|c|}{$(n=307)$} & \multicolumn{4}{|c|}{$(n=307)$} & & \\
\hline & & Mean & SD. & Mean & SD. & Mean & SD. & Mean & SD. & & \\
\hline \multirow{4}{*}{$\mathrm{H} 1$} & \multicolumn{11}{|c|}{ Corporate Trustworthiness } \\
\hline & Wisol & 3.45 & 1.05 & 3.99 & 0.681 & 3.42 & 1.25 & 3.42 & 1.25 & $\mathrm{EH}_{\mathrm{W} 1}=\left(\mathrm{O}_{\mathrm{W} 2}-\mathrm{O}_{\mathrm{W} 1}\right)-\left(\mathrm{O}_{\mathrm{W} 4}-\mathrm{O}_{\mathrm{W} 3}\right)$ & 0.54 \\
\hline & Socar & 3.47 & 0.816 & 3.99 & 0.576 & 3.25 & 1.03 & 3.25 & 1.03 & $\mathrm{EH}_{\mathrm{S} 1}=\left(\mathrm{O}_{\mathrm{S} 2}-\mathrm{O}_{\mathrm{S} 1}\right)-\left(\mathrm{O}_{\mathrm{S} 4}-\mathrm{O}_{\mathrm{S} 3}\right)$ & 0.52 \\
\hline & Rompetrol & 3.21 & 0.918 & 3.78 & 0.577 & 3.08 & 1.07 & 3.08 & 1.07 & $\mathrm{EH}_{\mathrm{R} 1}=\left(\mathrm{O}_{\mathrm{R} 2}-\mathrm{O}_{\mathrm{R} 1}\right)-\left(\mathrm{O}_{\mathrm{R} 4}-\mathrm{O}_{\mathrm{R} 3}\right)$ & 0.57 \\
\hline \multirow{4}{*}{$\mathrm{H} 2$} & \multicolumn{11}{|c|}{ Customer willingness to be involved in CSR activates } \\
\hline & Wisol & 3.24 & 0.815 & 3.98 & 0.843 & 3.25 & 1.14 & 3.25 & 1.14 & $\mathrm{EH}_{\mathrm{W} 2}=\left(\mathrm{O}_{\mathrm{W} 6}-\mathrm{O}_{\mathrm{W} 5}\right)-\left(\mathrm{O}_{\mathrm{W} 8}-\mathrm{O}_{\mathrm{W} 7}\right)$ & 0.74 \\
\hline & Socar & 3.31 & 0.668 & 3.99 & 0.7 & 3.29 & 1.00 & 3.29 & 1.00 & $\mathrm{EH}_{\mathrm{S} 2}=\left(\mathrm{O}_{\mathrm{S} 6}-\mathrm{O}_{\mathrm{S} 5}\right)-\left(\mathrm{O}_{\mathrm{S} 8}-\mathrm{O}_{\mathrm{S} 7}\right)$ & 0.68 \\
\hline & Rompetrol & 3.22 & 0.708 & 3.92 & 0.722 & 3.10 & 0.95 & 3.10 & 0.95 & $\mathrm{EH}_{\mathrm{R} 2}=\left(\mathrm{O}_{\mathrm{R} 6}-\mathrm{O}_{\mathrm{R} 5}\right)-\left(\mathrm{O}_{\mathrm{R} 8}-\mathrm{O}_{\mathrm{R} 7}\right)$ & 0.70 \\
\hline \multirow{4}{*}{ H3 } & \multicolumn{11}{|c|}{ Purchase intention } \\
\hline & Wisol & 3.38 & 1.02 & 3.91 & 1.16 & 3.37 & 1.08 & 3.37 & 1.08 & $E H_{\mathrm{W} 3}=\left(\mathrm{O}_{\mathrm{W} 10}-\mathrm{O}_{\mathrm{W} 9}\right)-\left(\mathrm{O}_{\mathrm{W} 12}-\mathrm{O}_{\mathrm{W} 11}\right)$ & 0.53 \\
\hline & Socar & 3.43 & 0.873 & 3.98 & 0.958 & 3.41 & 0.89 & 3.41 & 0.89 & $\mathrm{EH}_{\mathrm{S} 3}=\left(\mathrm{O}_{\mathrm{S} 10}-\mathrm{O}_{\mathrm{S} 9}\right)-\left(\mathrm{O}_{\mathrm{S} 12}-\mathrm{O}_{\mathrm{S} 11}\right)$ & 0.55 \\
\hline & Rompetrol & 3.29 & 0.915 & 3.86 & 1.067 & 3.27 & 1.04 & 3.27 & 1.04 & $\mathrm{EH}_{\mathrm{R} 3}=\left(\mathrm{O}_{\mathrm{R} 10}-\mathrm{O}_{\mathrm{R} 9}\right)-\left(\mathrm{O}_{\mathrm{R} 12}-\mathrm{O}_{\mathrm{R} 11}\right)$ & 0.57 \\
\hline
\end{tabular}

** Significant difference between post-CSR experimental group and pre-CSR experimental group at *p $<0.05$

\section{Annex4.}

The Results of Differential Analyses between Two Group Averages (Pre-CSR Group and Post-CSR Group) in the Experimental Group

\begin{tabular}{|c|c|c|c|c|c|c|c|c|}
\hline \multirow{4}{*}{ No. } & \multirow{4}{*}{$\begin{array}{l}\text { Dependent } \\
\text { Variables }\end{array}$} & \multicolumn{4}{|c|}{ Mean (SD.) } & \multirow{2}{*}{ T statistics } & \multirow{4}{*}{\multicolumn{2}{|c|}{$\begin{array}{l}95 \% \text { Confidence Interval } \\
\text { of the difference }\end{array}$}} \\
\hline & & \multicolumn{4}{|c|}{ Experimental Group } & & & \\
\hline & & \multicolumn{2}{|c|}{$\begin{array}{l}\text { Before CSR } \\
\text { Awareness } \\
\text { (Pre-CSR ) }\end{array}$} & \multicolumn{2}{|c|}{$\begin{array}{l}\text { After CSR } \\
\text { Awareness } \\
\text { (Post-CSR) }\end{array}$} & \multirow{2}{*}{$\begin{array}{l}\text { CSR Aware Group vs. } \\
\text { CSR Unaware Group } \\
\text { (Post-CSR vs. Pre-CSR) }\end{array}$} & & \\
\hline & & \multicolumn{4}{|c|}{$(\mathrm{n}=307)$} & & & \\
\hline \multirow{2}{*}{ H1 } & \multicolumn{6}{|c|}{ Corporate Trustworthiness } & & \\
\hline & Wisol & 3.45 & 1.05 & 3.99 & 0.68 & $2.471^{*}$ & 2.61801 & .12765 \\
\hline
\end{tabular}




\begin{tabular}{|c|c|c|c|c|c|c|c|c|}
\hline & Socar & 3.47 & 0.82 & 3.99 & 0.58 & $1.993^{*}$ & 2.52827 & .01840 \\
\hline & Rompetrol & 3.21 & 0.92 & 3.78 & 0.58 & $1.973^{*}$ & 2.71971 & .02775 \\
\hline \multirow{4}{*}{$\mathrm{H} 2$} & \multicolumn{6}{|c|}{ Customer willingness to be involved in CSR activates } & & \\
\hline & Wisol & 3.24 & 0.82 & 3.98 & 0.84 & $2.576^{*}$ & 2.91901 & .13874 \\
\hline & Socar & 3.31 & 0.67 & 3.99 & 0.7 & $2.839^{*}$ & 2.82421 & .12935 \\
\hline & Rompetrol & 3.22 & 0.71 & 3.92 & 0.72 & $2.597 *$ & 2.83222 & .14563 \\
\hline \multirow{4}{*}{ H3 } & \multicolumn{6}{|c|}{ Purchase intention } & & \\
\hline & Wisol & 3.38 & 1.02 & 3.91 & 1.16 & $1.990+$ & 2.11876 & .02798 \\
\hline & Socar & 3.43 & 0.87 & 3.98 & 0.96 & $1.973+$ & 2.31504 & .12565 \\
\hline & Rompetrol & 3.29 & 0.92 & 3.86 & 1.07 & $1.997+$ & 2.41918 & .12540 \\
\hline
\end{tabular}

$*_{p}<0.05 ;+p<0.10$ 